\title{
10. A MAN-MADE HOT SPRING ON THE OCEAN FLOOR 1,2
}

\author{
F. Duennebier and G. Blackinton, Hawaii Institute of Geophysics, University of Hawaii, Honolulu, Hawaii \\ and \\ J. Gieskes, Scripps Institution of Oceanography, University of California, San Diego, La Jolla, California ${ }^{2}$
}

\begin{abstract}
An instrument package emplaced in a deep-sea drill hole near the crest of the East Pacific Rise from the Glomar Challenger measured a rise in temperature at the bottom of the hole from $78^{\circ} \mathrm{C}$ shortly after drilling to $150^{\circ} \mathrm{C}$ after 42 days. The increase, not predicted by temperature measurements made before and during drilling, is probably the result of hot water rising from below and flowing out of the hole into the ocean. This was confirmed by the presence of a thin Mn-rich coating on the tool after it was recovered.
\end{abstract}

\section{INTRODUCTION AND OBSERVATIONS}

During Deep Sea Drilling Project (DSDP) Leg 65, a downhole seismometer package was emplaced from the Glomar Challenger in Hole $482 \mathrm{C}$ at the mouth of the Gulf of California about $12 \mathrm{~km}$ from the East Pacific Rise and south of the Tamayo Fracture Zone (Lewis, Robinson et al., 1979). The hole was drilled in $3 \mathrm{~km}$ of water through 143 meters of sediments and 47 meters of massive basalt. The instrument (Fig. 1), constructed at the Hawaii Institute of Geophysics, consisted of a downhole sensor package containing thermal sensors, seismometers, tiltmeters, and associated electronics. Signals from the sensors were multiplexed and digitized into a 16-channel format for transmission by wire to a data recording and power package located on the ocean floor. The recording package was connected by floating rope to an anchor-float assembly that can be commanded to surface for data tape recovery and refurbishing of the system (Duennebier and Blackinton, in press).

During drilling, temperatures were measured in the sediments with the Uyeda temperature probe, which uses a sensor that is inserted into the sediments below the drill bit and thus not affected by the drilling process. The temperatures showed a linear trend (Fig. 2) compatible with the heat-flow measurement of $12 \mathrm{HFU}$ made during the site survey (Lewis, this volume), if the conductivity of the sediments is assumed to be $2 \mathrm{mcal}$ $\mathrm{cm}^{-2} \mathrm{~s}^{-1}{ }^{\circ} \mathrm{C}^{-1}$. Using the same assumptions, the equilibrium temperature at the bottom of the hole should be between $90^{\circ}$ and $110^{\circ} \mathrm{C}$, depending on the conductivity of the basalt. Since this value was below the design maximum of the instrument package $\left(130^{\circ} \mathrm{C}\right)$, it was considered safe to deploy the sensor in the hole.

During emplacement of the downhole seismometer package, temperature measurements were made during two time periods separated by $11 \mathrm{hr}$. The first period was 30 minutes long and started about $7.5 \mathrm{hr}$. after

\footnotetext{
${ }^{1}$ Lewis, B. T. R., Robinson, P., et al., Init. Repts. DSDP, 65: Washington (U.S. Govt. Printing Office).

2 Adapted from article of same title by F. Duennebier and G. Blackinton, Nature, 284:338-340, March 27, 1980. Copyright (c) 1980, Macmillan Journals Limited.
}

water was last pumped into the hole. The temperature at the end of this period was $20 \pm 2.5^{\circ} \mathrm{C}$. By the end of the second period, $13.5 \mathrm{hr}$. later, the water temperature at the bottom of the hole had risen to $78 \pm 2.5^{\circ} \mathrm{C}$, a rate of increase of more than $4^{\circ} \mathrm{C} \mathrm{hr} .^{-1}$. This increase was assumed to be caused by the reheating of the hole after cooling by the drilling water.

After the second measurement period, the instrument was left to record data for 42 days and then recovered by the R/V Kana Keoki on 17 March 1979. When the recording package was recovered, the sensor package was again monitored in real time. Although most of the electronics, including the multiplexer and the a-to-d converter were still operating, few of the sensors seemed to be working, and there seemed to be little value in keeping the system operating. Therefore, the sensor package was removed from the hole. The package was coated with two materials: a thin black film and a slightly thicker, olive-brown crust, and showed obvious signs of excessive heat; both tiltmeters had exploded, and components and circuit boards that had been green before emplacement were now dark brown. Two components had mechanically shifted during emplacement, causing electrical short circuits through seawater to the recording package; however, the temperature sensors and circuitry were apparently undamaged. Although no data were obtained from the recording package, an additional 30 minutes of temperature information obtained during recovery showed that the temperature had risen dramatically during the time since emplacement. Because the temperature measurement obtained during recovery was greater than the maximum temperature for which the system had been calibrated $\left(130^{\circ} \mathrm{C}\right)$, the sensor package was calibrated for higher temperatures on its return to the Hawaii Institute of Geophysics and gave a value of 150 $\pm 5^{\circ} \mathrm{C}$ for the temperature in the hole. The new calibration values agreed with those taken before the experiment up to $130^{\circ} \mathrm{C}$; the values above $130^{\circ} \mathrm{C}$, while no longer linear (all components in the package were rated only to $125^{\circ} \mathrm{C}$ ), were repeatable. Thus we believe that that the $150 \pm 5^{\circ} \mathrm{C}$ value obtained after 42 days in the hole is valid. 


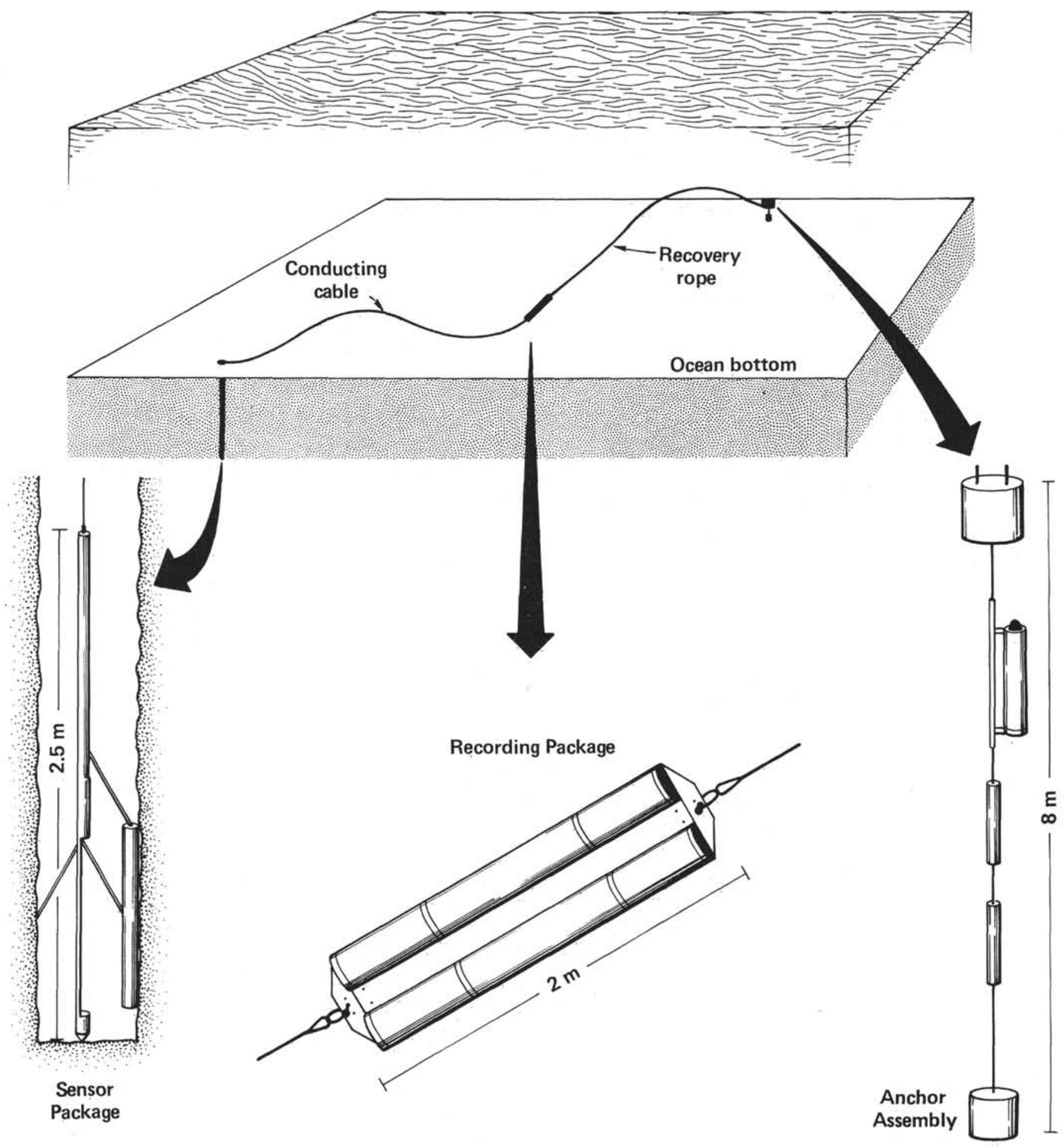

Figure 1. Configuration of ocean sub-bottom seismometer emplaced in Hole 482C. The sensor package was lowered to the bottom of the hole through the drill pipe by the Glomar Challenger. The pipe was then stripped from the wire and the recording package and anchor assembly attached and lowered to the ocean bottom.

The discrepancy between the predicted temperature at the bottom of the hole and the measured value can be explained if the hole acts as a conduit allowing hot water to rise from the more permeable basalt through the relatively impermeable sediments, forming a hot spring in the ocean bottom. By this mechanism, the hole would have heated over a period of time as hot water from below continued to enter the hole. To test this hypothesis, we analyzed for the manganese contents of: (1) a fragment of the casing of the downhole instrument, (2) a piece of olive-brown crust, and (3) an acid leach of the black flim. Acid dissolution in concentrated nitric acid and subsequent analysis of the relative contents of iron and manganese in these solutions yielded the following 


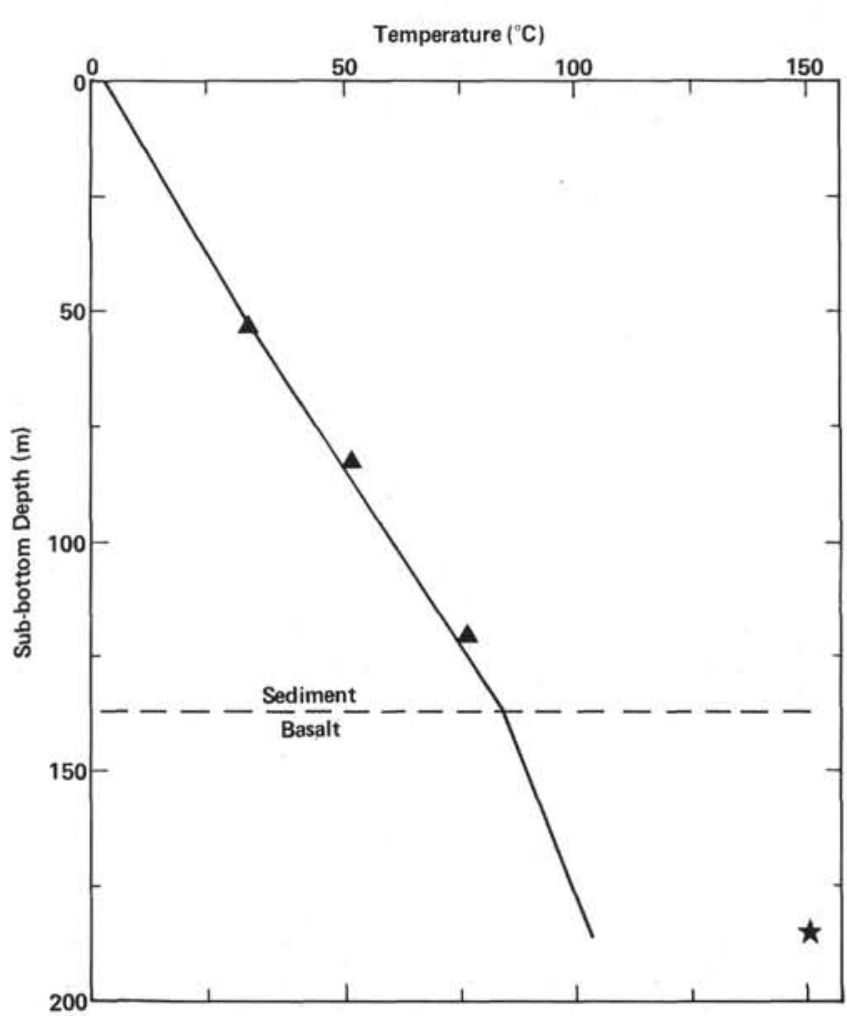

Figure 2. Temperature measurements made in Hole $482 \mathrm{C}$ during drilling (triangles) and at the bottom of the hole after 42 days (star). The temperature measured in the bottom of the hole at the end of the experiment $\left(150^{\circ} \mathrm{C}\right)$ was $50^{\circ} \mathrm{C}$ higher than the value extrapolated from measurements made in the sediments during drilling.

results $(\mathrm{Mn} / \mathrm{Fe}$ by weight): (1) $\mathrm{Mn} / \mathrm{Fe}=0.035$, (2) $\mathrm{Mn} / \mathrm{Fe}=0.07$, and (3) $\mathrm{Mn} / \mathrm{Fe}=0.18$. There is no doubt that dissolution of the black flim also involved dissolution of some of the original steel of the casing. Thus the film may have an $\mathrm{Mn} / \mathrm{Fe}$ ratio considerably higher than 0.18 . We conclude, therefore, that $\mathrm{Mn}$ oxide deposition has occurred on the outer casing of the instrument, consistent with the presumed upwelling of heated, manganese-enriched formation waters.

\section{CONCLUSIONS}

While there are other possible explanations for the temperature increase, we believe that the geochemical data can be explained only by hot spring activity. Many authors have suggested that hydrothermal circulation is responsible for erratic heat-flow values in the ocean (Parsons and Sclater, 1977; Anderson et al., 1977, 1979; Edmond and Gordon, 1979; Sclater and Crowe, 1979; Lawver and Williams, 1979; Epp and Suyenaga, 1978). Heat apparently is released in large amounts in regions where sediments are thin or where the basement protrudes through the sediments (Anderson et al., 1979). In areas where sediments are thick, the heat-flow tends to be lower than expected because of the blanketing effect of the sediments. The theory of Parsons and Sclater (1977) predicts a value of $17 \mathrm{HFU}$ for 0.5 m.y.-old crust, assuming conductive heat flow. Since the value measured at Site 482 was $12 \mathrm{HFU}$, heat was being lost at the site by means other than conduction even before drilling. The drill hole is an efficient conduit whereby heat can flow through the low permeability sediments by convection. Recent discoveries of natural hot springs at ridge crests (Edmond and Gordon, 1979) also document the importance of hydrothermal circulation in heat transfer near ridge crests and in the placement of hydrothermal ore deposits.

\section{ACKNOWLEDGMENTS}

We would like to thank Richard Hey and David Epp for helpful criticisms, Hans Brumsack for conducting the geochemical measurements, and Rita Pujalet for editorial assistance. This research was conducted under NSF grant OCE 78-10772.

\section{REFERENCES}

Anderson, R. N., Hobart, M. A., and Langseth, M. G., 1979. Geothermal convection through oceanic crust and sediments in the Indian Ocean. Science, 204:828-832.

Anderson, R. N., Langseth, M. G., and Sclater, J. G., 1977. The mechanisms of heat transfer through the floor of the Indian Ocean. J. Geophys. Res., 82:3391-3409.

Duennebier, F. K., and G. Blackinton, in press. The ocean subbottom seismometer. In Geyer, R. A. (Ed.), Geophysical Exploration at Sea: Boca Raton (CRC Press).

Edmond, J. M., and Gordon, L. I., 1979. Galapagos hot-springs revisited. Eos (Trans. Am. Geophys. Union), 60:281. [Abstract]

Epp, D., and Suyenaga, W., 1978. Thermal contraction and alteration of the oceanic crust. Geology, 6:726-728.

Lawver, L. A., and Williams, D. L., 1979. Heat flow in the central Gulf of California. J. Geophys. Res., 84:3465-3478.

Lewis, B. T. R., and Robinson, P., 1979. Leg 65 drills into young ocean crust. Geotimes, 24:16-18.

Parsons, B., and Sclater, J. G., 1977. An analysis of the variation of ocean floor bathymetry and heatflow with age. J. Geophys. Res., 82:803-827.

Sclater, J. G., and Crowe, J., 1979. A heat flow survey at Anomaly 13 on the Reykjanes Ridge; a critical test of the relation between heat flow and age. J. Geophys. Res., 84:1593-1602. 